\title{
Phenological synchrony and seasonality of eight tree species in a fragmented landscape in the Colombian Andes
}

\author{
Germán A. Corredor-Londoño ${ }^{1 *}$, José William Beltrán ${ }^{2}$, Alba Marina Torres-González ${ }^{3}$ \& \\ Antonella Sardi-Saavedra ${ }^{3}$ \\ 1. Universidad Nacional de Colombia, Facultad de Ciencias Agropecuarias, Carrera 32 No. 12-00, Palmira, Colombia; \\ gcorredorl@unal.edu.co \\ 2. Universidad del Pacífico, Department of Natural and Exact Sciences, Km 13 vía al aeropuerto, Barrio El Triunfo, \\ Buenaventura, Colombia; jwbeltran@unipacifico.edu.co \\ 3. Universidad del Valle, Departamento de Biología, Calle 13 No. 100-00, Cali, Colombia; \\ alba.torres@correounivalle.edu.co, antonellasardi06@gmail.com \\ * Correspondence
}

\section{Received 11-X-2019. C Corrected 29-iii-2020. Accepted 08-viii-2020.}

\begin{abstract}
Introduction: In Neotropical forests with high seasonality, climatic variables generally exert a strong influence on plant phenology. Objetive: To describe the reproductive phenology of eight tree species in a fragmented wet forest landscape, as well as to evaluate the seasonality and their phenological synchrony. Methods: The observations were performed over two years on the foothills of Los Farallones de Cali National Park, in Southwestern Colombia. We applied circular statistics to detect seasonal trends, calculate intraspecific synchrony and identify correlations between phenophases and climatic variables. Results: Flowering and fruiting were significantly seasonal in most species. The flowering and fruiting patterns were annual (e.g. Henriettea seemannii, Ocotea aurantiodora, Schefflera morototoni, Lacistema aggregatum) or sub-annual (e.g. Eugenia cf. egensis, Erythroxylum citrifolium, Miconia minutiflora, M. rubiginosa). The open flower and mature fruit phenophases at the community level were continual and bimodal. Each species had high intraspecific population synchrony of open flowers and ripe fruits. Precipitation, relative humidity, temperature and solar irradiance were correlated to flowering and fruiting peaks, except in E. cf. egensis. Conclusions: The annual species showed high phenological synchrony, although the rainfall regime showed variations between years; thus, they seem to be less sensitive to climatic variation than the sub-annual species. Our results indicate that climatic variables partially control the flowering and fruiting rhythms of eight tree species in this study.
\end{abstract}

Key words: secondary forest; tropical forest; tree phenology; reproductive phenology; climatic variables.

Corredor-Londoño, G.A., Beltrán, J.W., Torres-González, A.M., \& Sardi, A. (2020). Phenological synchrony and seasonality of eight tree species in a fragmented landscape in the Colombian Andes. Revista de Biología Tropical, 68(3), 987-1000.

Deforestation caused by anthropogenic activities has changed the Andean landscape to forests fragments, increasing edge effects that produce fine-scale variation in temperature, light, and soil humidity conditions (WilliamsLinera, Dominguez-Gastelu, \& García-Zurita, 1998). In fragmented landscapes the flowering and fruiting periods and frequency of breeding of tropical plants is affected, and such impacts on their reproductive success may disrupt biotic interactions and the goods and services that they provide (Herrerías-Diego, Quesada, Stoner, \& Lobo, 2006; Xiao, Li, Cao, \& Dong, 2016).

Phenological events in tropical plants can be regulated by abiotic and biotic factors, 
and also by phylogenetic constraints. Climate has been usually considered as the most important abiotic factor regulating plant phenology (Morellato et al., 2000; Morellato, 2003). In tropical forests with well-defined dry and rainy seasons, phenological patterns of plants are highly seasonal, with precipitation and soil humidity being the main factors that induce reproductive activities (Morellato, 2003; Nadia, Morellato, \& Machado, 2012). Flowering is often triggered by rainfall, with heavier rains inducing a higher synchronization of flowering within populations of different tree species (Morellato, Camargo, \& Gressler, 2013). Likewise, during the rainy season fruit production increases in many species (Sun et al., 1996; Villasana \& Suárez, 1997). However, in tropical areas with low climatic seasonality, photoperiod and light intensity are the main climatic factors that explain seasonal rhythms of growth and reproduction (Morellato et al., 2000; Gunter, Stimm, Cabrera, \& Diaz, 2008; Liuth, Talora, \& Amorin, 2013). On the other hand, biotic factors, such as attraction of pollinators and fruit dispersers, herbivory avoidance, and availability of animal agents in some periods of the year (van Schaik, Terborgh, \& Weight, 1993; Lobo et al., 2003; Hamann, 2004) can induce phenological responses. Thus, the arrival of migratory birds may be timed to flowering peaks of hummingbirdpollinated and fruiting peaks of bird-dispersed plants (van Schaik et al., 1993).

In addition, some studies have suggested that phenological patterns among related species might be constrained by phylogenetics membership (Wright \& Calderon, 1995; Staggemeier, Diniz-Filho, \& Morellato, 2010; Liuth et al., 2013). This hypothesis considers that phylogenetic constrains are stronger than local selective pressures, thus species within the same plant family or genus might have aggregate phenological pattterns in any geographical location (Kochmer \& Handel, 1986).

Studies of reproductive phenological patterns in transformed landscapes are fundamental to better understand the influence of triggers regulating growth and reproduction of plant species, assess the effects of global climate change, plant-animal interactions, and the dynamics of resource availability for populations of many animal species in tropical forests (Williams-Linera \& Meave, 2002; Morellato, 2003; Xiao et al., 2016). Moreover, phenological information can be used for implementation of an integrated conservation strategy, targeting restoration of plant communities and reintroduction of threatened plant species in protected natural areas, and it can also support ecological restoration programs, particularly for seed collection periods (Buisson, Alvarado, Stradic, \& Morellato, 2017; Luna-Nieves, Meave, Morellato, \& Ibarra-Manriquez, 2017; Nuñez-Cruz, Meave, \& Bonfil, 2018).

In this context, the present study is aimed at characterising, for the first time, the reproductive phenological pattern of eight birddispersed tree species, within in a mosaic of secondary fragments on the foothills of Los Farallones de Cali National Park in Southwestern Colombia, over two years of observations. The following research questions were addressed: 1) Are patterns of reproductive phenology of the species seasonal and related to climatic factors? 2) Do flowering and fruiting patterns differ between species? 3) Are the reproductive phenological patterns at the community level seasonal?

\section{MATERIALS AND METHODS}

Study area: Field work was carried out between February 2013 and March 2015 on the foothills of Los Farallones de Cali National Park, (3¹9'0.7' N \& 76³4'39" W), Municipality of Cali, Valle del Cauca Department, in Southwestern Colombia. The area is a subtropical wet forest in the Holdridge's system (Espinal, 1977) located at 1100-1 $180 \mathrm{~m}$, does not show major changes in physiognomy of evergreen vegetation between dry and wet seasons. The rainfall regime is bimodal, with a mean annual rainfall of $1481 \mathrm{~mm}$ and mean annual temperature of $24.3^{\circ} \mathrm{C}$ (Meteorological Station 26055070 Universidad del Valle, Institute of Hydrology, Meteorology and Environmental 
Studies, IDEAM). The dry seasons occur in December-February, and another, more one pronounced in June-August. Vegetation cover in the area includes successional stages from bushes and second-growth forests, interspersed with trails and county houses. Second-growth forest is characterized by a closed canopy with trees of 15-25 m high, with dominant tree species including Ocotea aurantiodora (Ruiz \& Pav.) Mez, Henriettea seemannii (Naudin) L.O. Williams, Lacistema aggregatum (P.J. Bergius) Rusby, Eugenia cf. egensis DC., Cupania americana L., and Calliandra pittieri Standl. The most heterogeneous bushes are distributed in patches with scattered trees with heights between 5 and $15 \mathrm{~m}$, dominated by Ladenbergia oblongifolia (Humb. ex Mutis) L. Andersson, H. seemannii, Miconia minutiflora (Bonpl.) DC., M. rubiginosa (Bonpl.) DC., and Schefflera morototoni (Aubl.) Maguire, Steyerm. \& Frodin (Corredor, 2017; Sardi, Torres, $\&$ Corredor, 2018).

Reproductive phenology: 15 adult individuals with a diameter at breast height (DBH) greater than five $\mathrm{cm}$ from the following eight tree species were evaluated: Scheffera morototoni (Araliaceae), Erythroxylum citrifolium A. St.-Hil. (Erythoxylaceae), Lacistema aggregatum (Lacistemataceae), Miconia minutiflora, M. rubiginosa, Henriettea seemannii (Melastomataceae) and Eugenia cf. egensis (Myrtaceae), except for Ocotea aurantiodora (Ruiz \& Pav.) Mez (Lauraceae) for which six male and eight female individuals were monitored. These species are frequently consumed by many frugivorous birds (G. Corredor, pers. obs.), have a high density and relative frequency in the study area (Corredor, 2017; Sardi et al., 2018) and exhibit ornithochory syndrome characteristics, including fleshy and showy fruits. The flowers of all species are visited by insects, mainly flies, bees and wasps (G. Corredor, pers. obs.).

During the two study years, observations were performed every two weeks using Nikon $8 \times 42$ binoculars, for a total of 48 censuses for all species except for $M$. rubiginosa, which was only monitored during the second year for a total of 24 censuses. The intensity of each reproductive phenophase (flower buds, open flowers, unripe fruits and ripe fruits) was defined following the semi-quantitative method proposed by Fournier (1974). Relative abundance of each phenophase was visually monitored always by the same observer, over the whole crown of each tree and assessing values between 0 and 4 , where $0=$ absence of the event, $1=1-25 \%, 2=26-50 \%, 3=51-75$ $\%$ and $4=76-100 \%$.

In order to characterise and compare the reproductive phenology of the species, we calculated the following phenological variables at the individual (variables iii, v) and population (variables i, ii, iv, vi) levels according to Auspurger (1983) and SanMartin-Gajardo \& Morellato (2003) as follows:

i) Total duration - number of months that a species remained in the flowering or fruiting phase.

ii) Mean duration - mean time in months that a species remained in flowering/fruiting, which corresponded to the sum of duration of the phenophase of each individual divided by the number of individuals in a species.

iii) Date of first flowering/fruiting - the first month that an individual started to flower/ fruit. For the statistical analyses, dates were converted to numerical values and each month was assigned a number from 1 (January) to 12 (December).

iv) Date of first synchrony - standard deviation of the mean of the dates of first flowering/fruiting.

v) Peak date of flowering/fruiting - month of maximum intensity of flowering or fruiting for an individual according to the Fournier index (1974).

vi) Population synchrony index $(Z)$ - estimates the overlap of the flowering or fruiting periods between individuals of the same species, and defined by Auspurger (1983): $\mathrm{Z}=\Sigma \mathrm{X} i / \mathrm{N}$

Where $\mathrm{X} i$ is the index of synchrony for an individual $i$ and $\mathrm{N}$ is individuals number in 
a populacion. When $\mathrm{Z}=1$ it indicates total synchrony or flowering/fruiting periods of all individuals in a population occur on the same time of year; when $Z=0$, indicates no synchrony or flowering/fruiting periods of all individuals in a population do not show any overlap.

The production of open flowers in $M$. minutiflora was difficult to assess due to the extremely brief duration of this phenophase (i.e. 4 days); therefore, the phenological variables in this species were calculated using flower bud data.

Data analysis: The monthly phenological intensity values of individuals of each species and at the community level were added and divided by the maximum possible value (i.e. total number of individuals multiplied by four). Each value was multiplied by 100 to obtain percentages. For $O$. aurantiodora, the female and male flowering individuals were monitored, and only fruiting female individuals were considered. In $S$. morototoni, records of unripe and ripe fruits were pooled due to the difficulty of differentiating changes in fruit colour in very high trees.

The frequency and duration of each phenophase per year was established according to Newstrom, Frankie, \& Baker (1994). The frequencies of each species were classified as follows: 1) continual (flowering or fruiting throughout the year but with brief and sporadic breaks), 2) sub-annual (more than one event per year) and, 3) annual (only one event per year).

Since most of the phenology data for each species did not show a normal distribution (Kolmogorov-Smirnov test), Spearman's correlation coefficients (Sokal \& Rohlf, 1995) were calculated to verify whether the Fournier monthly intensity index for each species was related to climatic variables (i.e. total precipitation, percentage of mean relative humidity, mean temperature, total solar irradiance) from one, two and three months prior to data collection. Statistical analyses were performed using Minitab 17 software. A circular statistical analysis (Zar, 2010) based on the proportion of individuals in each phenophase was carried out to evaluate possible seasonal patterns. The sampling days of each individual of all species were converted to an angle, with 365 days equalling $360^{\circ}$. We converted the values of sampling dates into angles representing the months of the year $\left(\right.$ January $=15^{\circ}$ to December $=345^{\circ}$, in intervals of $30^{\circ}$ ). The frequencies of monthly occurrence of open flowers and mature fruits converted into polar coordinates were used to calculate the mean angle (a), which indicates the date or month when the phenophase data tended to be concentrated, and the length vector (r) shows the concentration frequency around the mean angle and has values between 0 and 1 . This last variable can be considered a seasonality index when the mean angle is significant (Morellato et al., 2000; Morellato, Alberti, \& Hudson, 2010). Mean dates were determined by converting the directions of mean angles to their corresponding mean dates. To determine the significance of the mean angle, we performed a Rayleigh test ( $\mathrm{z}$ ) to verify whether the data were evenly distributed around the circle (null hypothesis) or not (Zar, 2010). If the mean angle was significant, we rejected the null hypothesis and accepted the existence of a seasonal pattern (Morellato et al., 2000; Morellato et al., 2010). The circular analyses were performed using Oriana 4.02 (Kovach Computing Services, 2013).

A Kruskal-Wallis test was used to verify whether significant differences occurred in phenological variables between species (Zar, 2010). The following phenological variables were compared: total duration, date of first flowering/fruiting, peak date of flowering/fruiting and synchrony of individuals. We compared the flowering and fruiting patterns at the population level with a paired Student's t test to examine whether significant differences occurred between years.

\section{RESULTS}

Reproductive phenology of species: All species showed a high reproductive seasonality; 
four of them (H. seemannii, O. aurantiodora, $S$. morototoni and L. aggregatum) showed annual phenological patterns (Fig. 1, Fig. 2) and other four species (E. cf. egensis, E. citrifolium, $M$. minutiflora and M. rubiginosa) exhibited sub-annual patterns in flowering and fruiting (Fig. 2, Fig. 3).

Flowering was concentrated in the dry season in four species $(O$. aurantiodora, L. aggregatum, M. minutiflora and M. rubiginosa), with one or two peaks per year, usually in JanuaryFebruary and July up to September for both years (Fig. 1, Fig. 3). M. minutiflora showed a higher flowering peak in January (Fig. 3). Conversely, in the other species the flowering peak occurred mainly during the rainy season, in May and/or September-October for both years (Fig. 1, Fig. 2).

Mean flowering peak was seasonal, with similar flowering patterns for both years, and differences in date of ocurrence of the phenophase among species (Digital appendix 1). The production of flower buds was correlated positively with three climatic variables in five species; $H$. semmani exhibited the strongest correlation with radiation in one, two and three preceding months (Digital appendix 2). This phenophase was also correlated negatively with rainfall and relative humidity, the strongest correlation being with rainfall after three- and twomonth time lags (Digital appendix 2). Anthesis was correlated significantly with all climatic variables in one species, $S$. morototoni (Digital appendix 2).

Fruiting occurred in all months during the study period, with evident peaks for ripe fruits from September to November in L. aggregatum and $E$. cf. egensis (in the first year), in the rainy season. Whereas M. minutiflora had the highest fruiting peak in May, for both years, also in the rainy season (Fig. 2, Fig. 3). O. aurantiodora fruited all year around, with sligh peaks in April and May (Fig. 1). Conversely, in the other three species (H. semmnii, S. morototoni, and $E$. citrifolium) fruiting was concentrated mainly in December-February or July-August, during the dry or in the transition between dry and rainy season (Fig. 1, Fig. 2). M. rubiginosa was the only species that did not show seasonality in fruiting. Date of mean fruiting peak was seasonal, exhibiting similar fruiting patterns for both years, with interspecific differences in the period of occurrence (Digital appendix 3). $H$. semmanii, S. morototoni, L. aggregatum, and M. minutiflora showed similar fruiting patterns for both years.

Unripe fruits in S. morototoni and $M$. rubiginosa were correlated with the four climatic variables. $M$. rubiginosa showed the strongest positive relationship with solar irradiance three months before the event. Ripe fruits in $O$. aurantiodora showed a positive relationship with rainfall in the three preceding months, and a negative relationship with temperature in the two preceding months. $L$. aggregatum had a negative correlation with relative humidity in two and three-month time lags (Digital appendix 2).

At the community level, flowering was continual through all the study period (Fig. 3), without significant differences between years (Digital appendix 1; $\mathrm{t}=0.87, \mathrm{P}=0.39$ ). The highest flowering peak was in August-September in the dry-to-rainy season transition, and it was less pronounced in the second year. (Fig. 3 ). Fruiting was also continual and seasonal, showing the same pattern in both years (Digital appendix 3, Fig. 3), without differences (t $=0.33, \mathrm{P}=0.75)$. The highest percentage of individuals with ripe fruits was observed in the rainy season, mainly during SeptemberNovember (Fig. 4).

Phenological variables of flowering and fruiting: Significant differences were found in flowering duration $(\mathrm{H}=57.97, \mathrm{P}<0.001)$, date of first flowering $(\mathrm{H}=62.17, \mathrm{P}<0.001)$, flowering peak $(\mathrm{H}=64.51, \mathrm{P}<0.001)$ and flowering synchrony $(\mathrm{H}=61.77, \mathrm{P}<0.001)$ among the eight species. Total flowering duration was highly variable among species and fluctuated between one and seven months (Digital appendix 4). The high standard deviation values of average date of first flowering and average peak of anthesis indicated a strong variation among individual of the same species, 

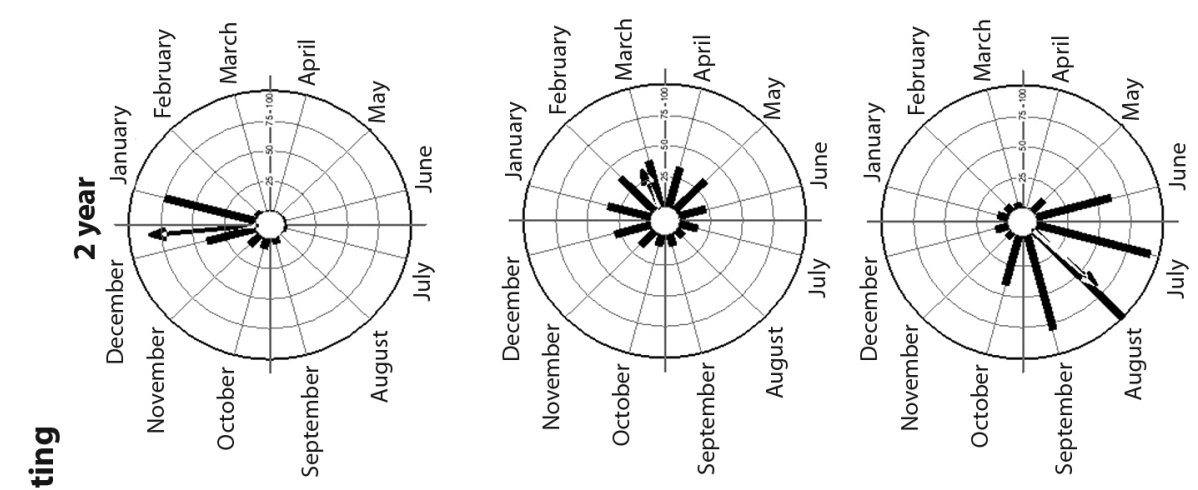

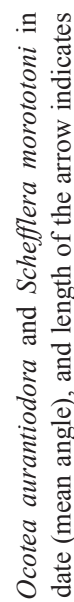
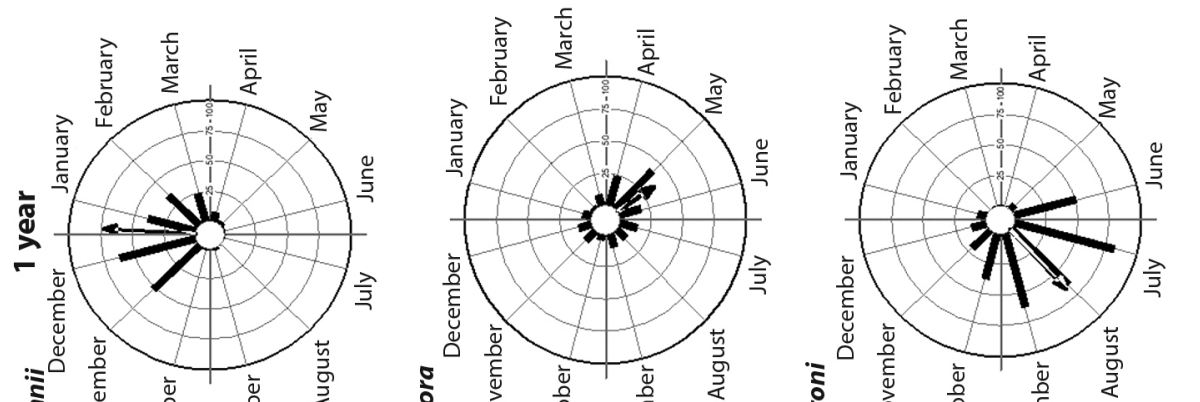

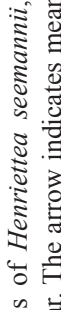
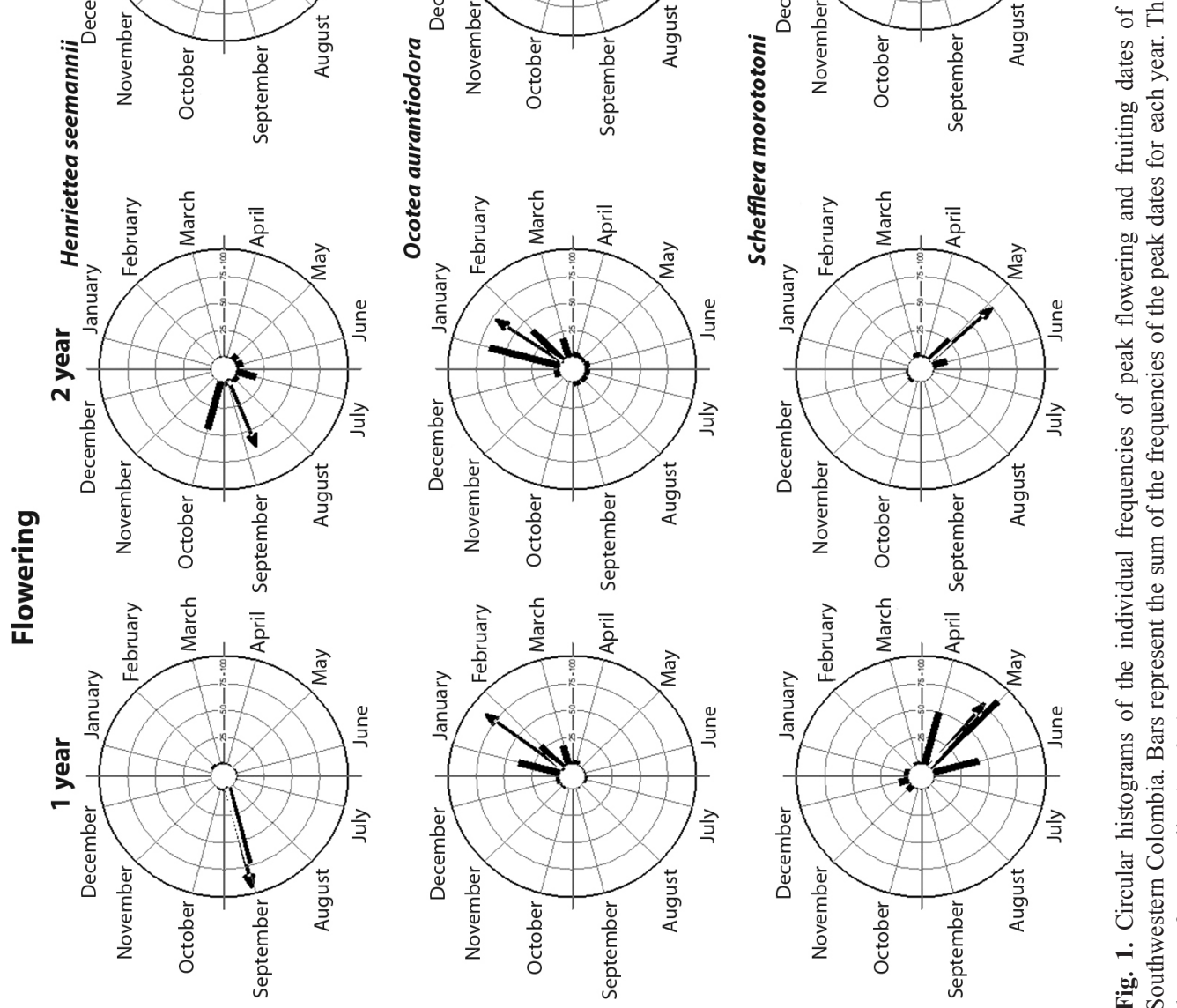

章

造站

苋

$+$

$\frac{0}{0}$

可

西

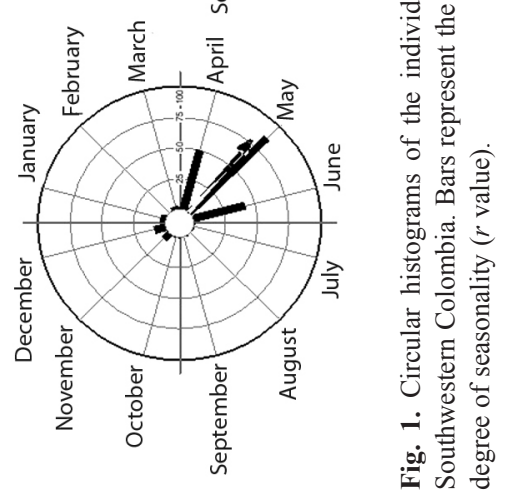




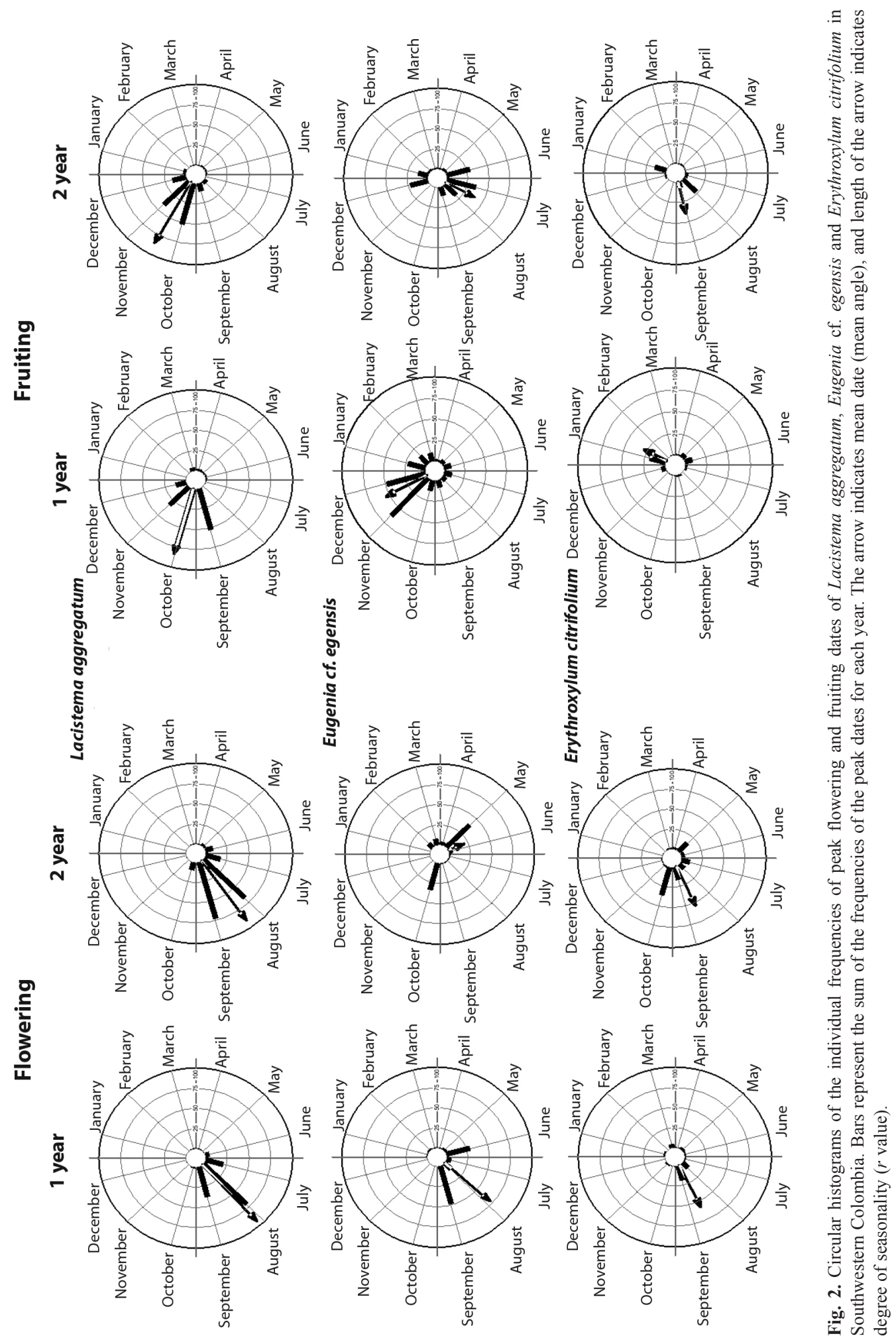



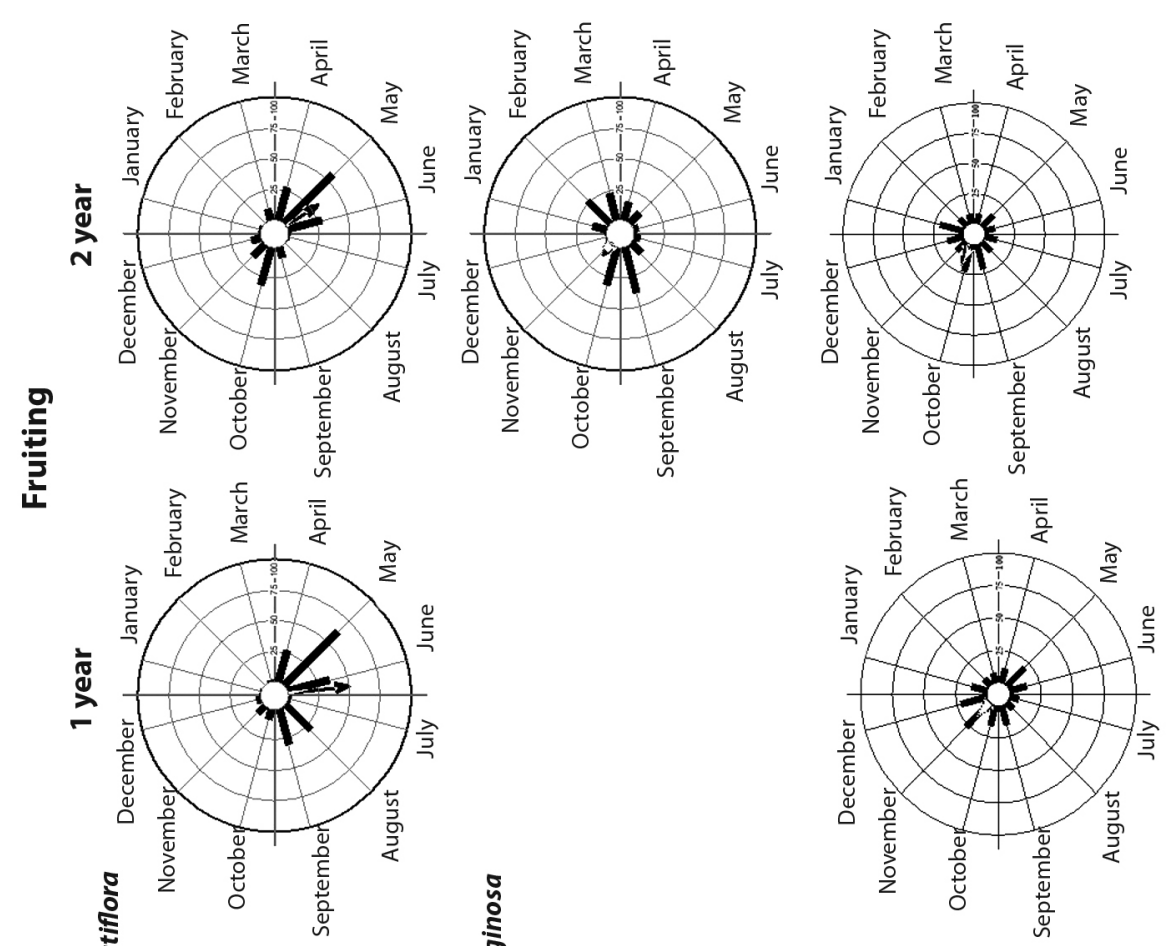

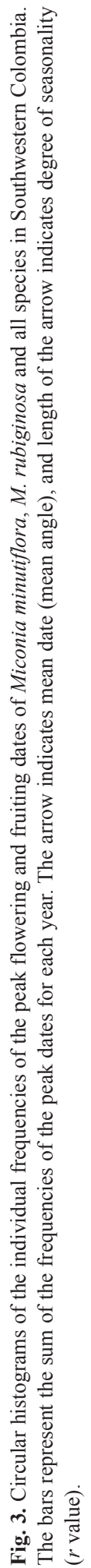

ปั
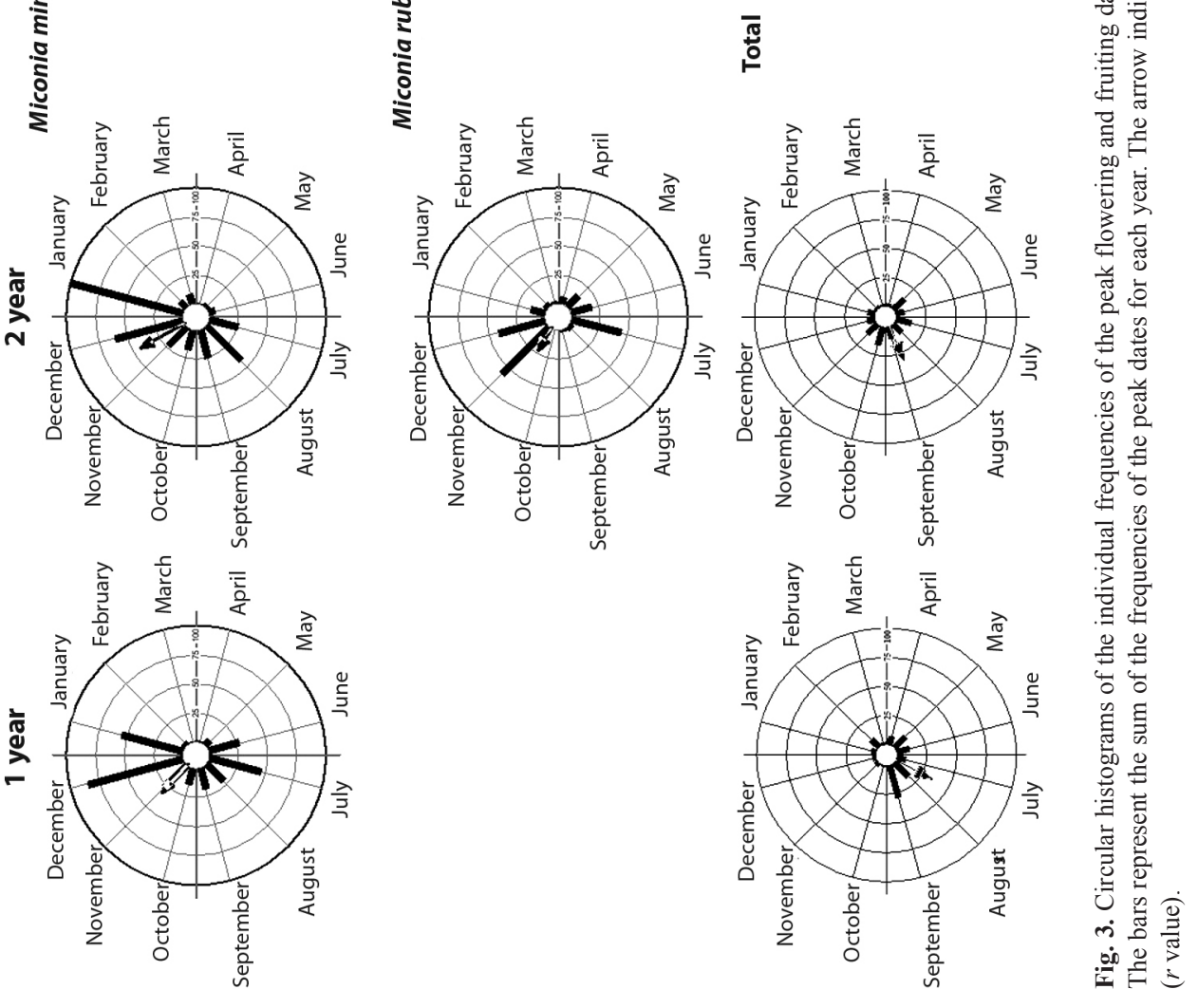


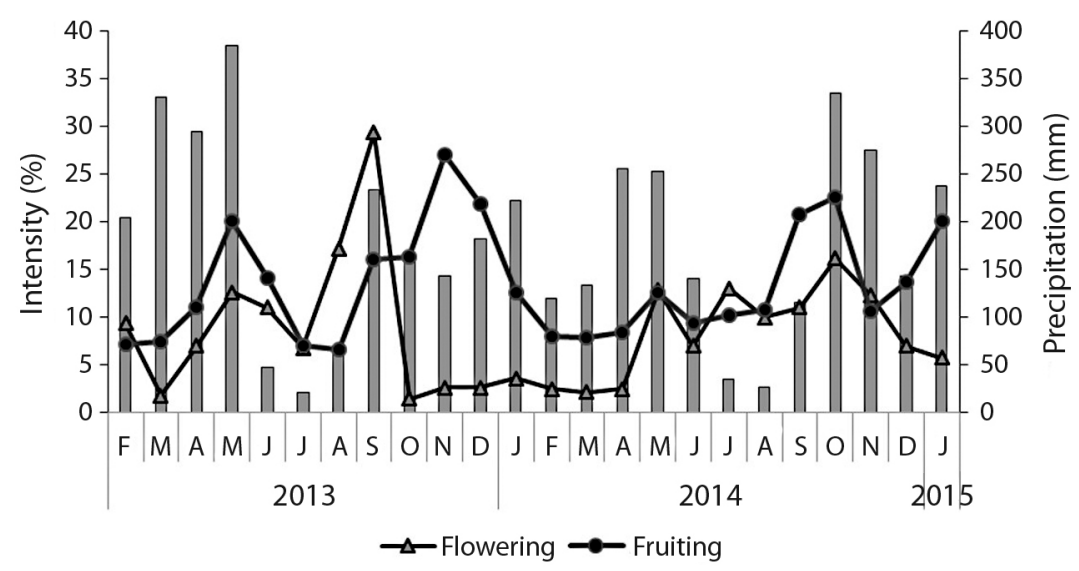

Fig. 4. Monthly rainfall and mean intensity index of flowering and fruiting at community level from February 2013 to January 2015, in Southwestern Colombia.

especially in $M$. minutiflora. However, almost all species showed high rates of synchrony at the population level (values between 0.62 and 0.96 ), with the exception of $O$. aurantiodora and E. citrifolium (Digital appendix 4).

The eight species showed significant differences in the duration of fruiting $(\mathrm{H}=48.24$, $\mathrm{P}<0.001)$, date of first fruiting $(\mathrm{H}=32.58, \mathrm{P}<$ $0.001)$, peak of fruiting $(\mathrm{H}=77.72, \mathrm{P}<0.001)$ and fruiting synchrony $(\mathrm{H}=23.94, \mathrm{P}<0.001)$. The duration of ripe fruits was highly variable and ranged from two-three months in $E$. citrifolium to eight months in $O$. aurantiodora. In most species, high synchrony indexes were found at the population level (between 0.55 and 0.91; Digital appendix 5).

\section{DISCUSSION}

Differences in flowering patterns among species seem to support the hypothesis of shared pollinators, in which interspecific competition by pollinators is a selective pressure that leads to segregation of flowering events among species (Rathcke \& Lacey, 1985); flowering was sequential in most species, especially in the second year. However, we have limited information on pollination ecology of the study species to evaluate this hypothesis. Moreover, the occurrence of species with ripe fruits throughout the year and staggered fruiting peaks could indicate interspecific competition for seed dispersers (see Wheelwright, 1986). In all species, a sequential fruiting habit was observed, which could maximize fruit dispersal by birds (Poulin, Wright, Lefebvre, \& Calderón, 1999; Dew \& Boubli, 2005). This phenomenon could partially support the hypothesis of interspecific competition.

The annual and sub-annual flowering and fruiting patterns were different among species, and significant differences were observed in the duration of flowering, date of first flowering, peak of flowering and flowering synchrony. The intensity patterns of ripe fruit were equally variable between species and significantly different in terms of fruit duration, date of first fruiting and peak of fruiting. These variations in phenological patterns have also been reported in others tropical wet forests, where several biotic and abiotic factors controlling the reproductive phenology of tree species are involved (Chapman, Wrangham, Chapman, Kennard, \& Zanne, 1999; Hamann, 2004; Liuth et al., 2013).

Species with annual phenological patterns (i.e. H. seemannii, S. morototoni, L. aggregatum) showed a greater temporal similarity among years, greater synchrony and higher 
levels of phenological intensity than sub-annual species. The only exception was $O$. aurantiodora, which had low synchrony and intensity in flowering; this dioecious species had sparse and continual year-round fruiting. This same fruiting pattern was found in Ocotea pulchella in Brazil (Bauer, Muller, Nunes, Goetz, \& Schmitt, 2014). A low flowering synchrony and high variation in flowering intensities among individuals have also been described for $O$. catharinensis and other Lauraceae species (Wheelwright, 1986; Montagna, Silva, Pikart, \& Reis, 2018). In this study, annual species showed higher phenological synchrony than sub-annual species, and this pattern was similar in both years. Similar results of high synchrony in the phenological patterns for annual species were found in other tropical forests (SanMartin-Gajardo \& Morellato 2003; Liuth et al., 2013; Luna-Nieves et al., 2017). Due to the apparent low plasticity, annual species could be less sensitive to climatic variation. In the tropics, climate affects phenological patterns in terms of time, duration and synchrony as well as the dynamics of other organisms that depend on these cycles (Singh \& Kushwaha, 2006; Cleland, Chuine, Menzel, Mooney, \& Schwartz, 2007). Detected variation in the phenological patterns of sub-annual species among years supports the need to conduct long-term studies on reproductive phenology in the study area, because inter-annual variations in the number and duration of flowering and fruiting cycles have been found in other tropical tree species (Newstrom et al., 1994; Vilchez \& Rocha, 2007; Menezes, Couto-Santos, \& Funch, 2018).

In other tropical forests, a high degree of individual synchrony has also been found in flowering peaks. For example, high synchrony among individuals with open flowers has been recorded in O. pulchella, Eugenia involucrata, E. hiemalis in Southern Brazil (Athayde, Giehl, Budke, Gesing, \& Eisingeret, 2009), and Erythroxylum havanense in Mexico (Dominguez \& Dirzo, 1995), as well as in the family Myrtaceae (Smith-Ramirez, Armesto, \& Figueroa, 1998). In this study, the highly synchronized flowering peak in M. minutiflora (Mori \& Pipoly, 1984), which lasted less than four days, did not coincide with the bi-monthly record of phenological data. Therefore, phenological studies of this species should include observations every week once flowering begins. The high synchrony between individuals of a species suggests it responds to different environmental signals that promote synchronous flowering (Bernier, Kinet, \& Sachs, 1981). The high synchrony of flowering increases the visibility of flowers and it is associated with greater attractiveness for pollinators and thus can improve reproductive success (Staggemeier et al., 2010; Pires, Silva, \& Freitas, 2014).

Considering the bimodal pattern of precipitation in the study area, we found that the dry season was more severe in the first period (i.e. June to August) than in the second (i.e. December to February), and this condition appears to influence the flowering and fruiting patterns of the tree population. Flowering of most species occurred during the severe dry period and its transition to the rainy period. This pattern of flowering in the dry season has been observed frequently in other tropical forests (Murali \& Sukumar, 1994; Mclaren \& McDonald, 2005; Lacerda, Rossato, RibeiroNovae, \& de Almeida, 2018), where the hot dry season favours plant pollination (Wright $\&$ Calderon, 1995). On the other hand, the highest fruiting intensity of most species occurred during the two rainy seasons and extended to the moderate dry season (i.e. December to February), and apparently corresponds to a period when water stress is not very high in the study area. Similarly, a greater production of ripe fruits in several species of the family Melastomataceae occurred during the rainy season in the Colombian Andes (Kessler-Rios \& Kattan, 2012). Similarly, in a rainforest of the Colombian Pacific, the highest occurrence of ripe fruits of many tree species was recorded in the rainy season (Hilty, 1980). The highest fruit abundance in the rainiest season is common in tropical forests, especially in areas with a well-defined dry season, coinciding with the 
greatest activity of frugivorous animals (Poulin et al., 1999; Thies \& Kalko, 2004).

In the study area, a general fruit scarcity was observed in the tree community during the dry season; however, S. morototoni showed the highest fruit production. Fruits of $S$. morototoni are consumed by many bird species (Saracco, Collazo, Groom, \& Carlo, 2005; G. Corredor, pers. obs.). In consequence, we suggest that S. morototoni may be a keystone species for frugivorous birds in this area, since it produces fruits during a period of limited fruit availability. S. morototoni is also suggested a keystone species during the dry season for many frugivorous birds in central Amazonian (Parrini, Raposo, del Hoyo \& da Silva 2012). The intensity of ripe fruits production was highly variable among species, and occurred at different times of the year. For example, $M$. minutiflora and $M$. rubiginosa did not fruit at the same time in both years, which could represent a strategy to reduce competition from seed dispersal birds (Poulin et al., 1999). In fact, variation in the time of ripe fruit production of can affect food availability for frugivorous animals, and their abundance (Dew \& Boubli, 2005; Hanya et al., 2011). High food availability during the rainy season was also related to an increase in the diversity of resident and long-distance migratory birds (G. Corredor, pers. obs.).

In general, the phenological responses of plants to environmental stimuli present a lag of several weeks or months after the occurrence of events (Nadia et al., 2012; Liuth et al., 2013; Menezes et al., 2018). In this study, correlations between environmental variables that occurred between one and three months prior to the event and the phenological phases were not strong, indicating that the flowering and fruiting patterns of the species cannot be completely explained by the climatic variables analysed. Consequently, there does not seem to exist a strong environmental selective pressure that controls the reproductive phenology of the study species. Other abiotic or biotic factors could help to explain the phenological patterns observed over time. These may include genetic aspects or complex biological interactions between the local tree and shrub community, pollinators and seed dispersers (Nadia et al., 2012; Carvalho, Somner, \& Allen, 2015). To the best of our knowledge, previous studies have not focused on the genetic and biotic factors that cause the reproductive phenology of tree species in the Colombian Andes; therefore, we cannot confirm the contribution of genetic factors. However, Kessler-Rios \& Kattan (2012) have shown that the reproductive periods of frugivorous birds and the production of ripe fruits of trees and shrubs of Melastomataceae are highly synchronized in the Colombian Andes, which supports the relevance of considering ecophysiological aspects that shape plant phenology and the activity patterns of the associated fauna. Future studies considering long-term monitoring flower and fruit production during annual cycles could help us understand the effects of climatic variations on plant reproduction, and level of synchrony among species, especially on fragmented landscapes in the Colombian Andes. Understanding reproductive patterns of plants will be important for predicting impacts of climate change on flora and fauna across the region.

Ethical statement: authors declare that they all agree with this publication and made significant contributions; that there is no conflict of interest of any kind; and that we followed all pertinent ethical and legal procedures and requirements. All financial sources are fully and clearly stated in the acknowledgements section. A signed document has been filed in the journal archives.

\section{ACKNOWLEDGMENTS}

We thank Pedro José Cardona for their assistance in the field work, Mercedes Andrade for her advice on statistical analyses, and the Loma Larga private reserve for permiting this study in the area. This work was supported by the Universidad del Valle through the internal call 2012, CI 7897 and the support programme for doctoral students 2015, CI 71015, which was granted to the first author. We thank to 
the research vice-chancellor of Universidad del Valle for supporting the English translation in the earlier version of the manuscript by the American Journal Experts (AJE). Finally, we thank two anonymous reviewers for the valuable contributions to the manuscript.

\section{RESUMEN}

Sincronía fenológica y estacionalidad de ocho especies de árboles en un paisaje fragmentado en los Andes colombianos. Introducción: En bosques neotropicales con alta estacionalidad, las variables climáticas generalmente ejercen una fuerte influencia en la fenología de plantas. Objetivo: Describir la fenología reproductiva de ocho especies de árboles en un paisaje fragmentado de bosque húmedo, y analizar la estacionalidad y su sincronía fenológica. Métodos: Las observaciones fueron realizadas durante dos años en el piedemonte del Parque Nacional Los Farallones de Cali, suroccidente de Colombia. Utilizamos estadística circular para detectar tendencias estacionales, calcular sincronía intraespecífica, e identificar correlaciones entre fenofases y variables climáticas. Resultados: La floración y fructificación fueron significativamente estacionales en la mayoría de especies. Los patrones de floración y fructificación fueron anuales (e.g. Henriettea seemannii, Ocotea aurantiodora, Schefflera morototoni, Lacistema aggregatum), o sub-anuales (e.g. Eugenia cf. egensis, Erythroxylum citrifolium, Miconia minutiflora, $M$. rubiginosa). Las fenofases flores abiertas y frutos maduros a nivel de comunidad fueron continuas y bimodales. Cada especie presentó una alta sincronía intraespecifica de flores abiertas y frutos maduros. La precipitación, humedad relativa, temperatura y radiación solar estuvieron correlacionadas con los picos de floración y fructificación, excepto en Eugenia cf. egensis. Conclusiones: Las especies anuales mostraron una alta sincronía fenológica, a pesar de que la precipitación mostró variaciones entre años; dichas especies parecen ser menos sensibles a la variación climática que las especies sub-anuales. Nuestros datos indican que las variables climáticas controlan parcialmente los ritmos de floración y fructificación de las ocho especies arbóreas estudiadas.

Palabras clave: bosque secundario; bosque tropical; fenología de árboles; fenología reproductiva; variables climáticas.

\section{REFERENCES}

Athayde, E.A., Giehl, L.H., Budke, J.C., Gesing, J.P.A., \& Eisingeret, S.M. (2009). Fenologia de espécies arbóreas em uma floresta ribeirinha em Santa Maria, sul do Brasil. Revista Brasileira de Biociências, 7, 43-51.
Auspurger, C.K. (1983). Phenology, flowering synchrony, and fruit set of six Neotropical shrubs. Biotropica, $15,257-267$.

Bauer, D., Muller, A., Nunes, M., Goetz, B., \& Schmitt, J.L. (2014). Fenologia de Ocotea pulchella, Myrcia brasiliensis e Psidium cattleyanum, em floresta semidecídua do sul do Brasil. Floresta, 44, 657-668.

Bernier, G., Kinet, J.M., \& Sachs, R.M. (1981). The physiology of flowering. Florida, USA: CRC Press Inc.

Buisson, E., Alvarado, S., Stradic, S.L., \& Morellato, L.P.C. (2017). Plant phenological research enhances ecological restoration. Restoration Ecology, 25, 164-171.

Carvalho, A.L.G., Somner, G.V., \& Allen, J. (2015). Is the phenology of all restinga species the same? A taxonomically-focused study of Sapindaceae in a highly threatened coastal enviroment. Flora, 215, 92-101.

Chapman, A., Wrangham, R.W., Chapman, L.J., Kennard, D.K., \& Zanne, A.E. (1999). Fruit and flower phenology at two sites in Kibale National Park, Uganda. Journal of Tropical Ecology, 15, 189-211.

Cleland, E.E., Chuine, I., Menzel, A., Mooney, H.A., \& Schwartz, M.D. (2007). Shifting plant phenology in response to global change. Trends in Ecology and Evolution, 22, 357-365.

Corredor, G.A. (2017). Hábitat, su uso e historia natural del tinamú chico (Crypturellus soui) en el piedemonte de los Farallones de Cali (Tesis de doctorado). Universidad del Valle, Colombia.

Dew, J.L., \& Boubli, J.P. (2005). Tropical fruits and frugivorous: The search for strong interactors. Dordrecht, Netherlands: Springer.

Dominguez, C.A., \& Dirzo, R. (1995). Plant-herbivore interactions in Mesoamerican tropical dry forests. In S.H. Bullock, E. Medina, \& H.A. Mooney (Eds.), Seasonally dry tropical forests (pp. 304-325). Cambridge, Great Britain: Cambridge University Press.

Espinal, L.S. (1977). Zonas de vida o formaciones vegetales de Colombia (Vol. 13). Bogotá D.E, Colombia: Instituto Geográfico "Agustín Codazzi”.

Fournier, L.A. (1974). Un método cuantitativo para la medición de características fenológicas en árboles. Turrialba, 24, 422-423.

Gunter, S., Stimm, B., Cabrera, M., \& Díaz, M.L. (2008). Tree phenology in montane forests of Southern Ecuador can be explained by precipitation, irradiance and photoperiodic control. Journal of Tropical Ecology, 24, 247-258.

Hamann, A. (2004). Flowering and fruiting phenology of a Philippine submontane rain forest: climatic factors as 
proximate and ultimate causes. Journal of Ecology, $92,24-31$.

Hanya, G., Stevenson, P., van Noordwijk, M., Wong, S.T., Kanamori, T., Kuze, N., ... van Schaik, C. (2011) Seasonality in fruit availability affects frugivorous primate biomass and species richness. Ecography, 34, 109-1017.

Herrerías-Diego, Y., Quesada, M., Stoner, K.E., \& Lobo, J.A. (2006). Effects of forest fragmentation on phenological patterns and reproductive success on the tropical dry forest tree Ceiba aesculifolia. Conservation Biology, 20, 1111-1120.

Hilty, S.L. (1980). Flowering and fruiting periodicity in a premontane rain forest in pacific Colombia. Biotropica, 12, 292-306.

Kessler-Rios, M.M., \& Kattan, G.H. (2012). Fruits of Melastomataceae: phenology in Andean forest and role as a food resource for birds. Journal of Tropical Ecology, 28, 11-21.

Kochmer, J.P., \& Handel, S.N. (1986). Constraints and competition in the evolution of flowering phenology. Ecological Monographs, 56, 303-325.

Kovach Computing Services. (2013). Oriana (version 4.02). Retrieved from https://www.kovcomp.co.uk/ oriana/index.html

Lacerda, D.M.A., Rossato, D.R., Ribeiro-Novaes, E.K.M.D, \& de Almeida Jr., E.B. (2018). Reproductive phenology differs between evergreen and deciduous species in a Northeast Brazilian savanna. Acta Botanica Brasilica, 32, 367-375.

Lobo, J.A., Quesada, M., Stoner K.E., Fuchs, E.J., Herrerías-Diego, Y., Rojas, J., \& Saborio, G. (2003). Factors affecting phenological patterns of Bombacaceus trees in seasonal forests in Costa Rica and Mexico. American Journal of Botany, 90, 1054-1067.

Liuth, H.S., Talora, D.C., \& Amorim, A.M. (2013). Phenological synchrony and seasonality of understory Rubiaceae in the Atlantic Forest, Bahia, Brazil. Acta Botanica Basilica, 271, 195-204.

Luna-Nieves, A.L., Meave, J.A., Morellato, L.P.C., \& Ibarra-Manriquez, G. (2017). Reproductive phenology of useful seasonally dry tropical forest trees: Guiding patterns for seed collection and plant propagation in nurseries. Forest Ecology and Management, 397, $52-62$.

Mclaren, K.P., \& McDonald, M.A. (2005). Seasonal patterns of flowering and fruiting in a dry tropical forest in Jamaica. Biotropica, 37, 584-590.

Menezes, I.S., Couto-Santos, A.P.L., \& Funch, L.S. (2018) The influence of El Niño and edge effects on the reproductive phenology and floral visitors of Eschweilera tetrapetala Mori (Lecythidaceae), an endemic species of the Atlantic Forest of northeastern Brazil. Acta Botanica Brasilica, 32, 1-11.

Montagna, T., Silva, J.Z., Pikart, T.G., \& Reis, M.S. (2018). Reproductive ecology of Ocotea catharinensis, an endangered tree species. Plant Biology, 20, 926-935.

Morellato, L.P.C. (2003). South America. In M.D. Schwartz (Ed.), Phenology: An Integrative Environmental Science (pp. 75-92). Dordrecht, The Netherlands: Kluwer Academic Publishers.

Morellato, L.P.C., Alberti, L.F., \& Hudson, I.L. (2010). Applications of circular statistics in plant phenology: a case studies. In M. Keatley \& I.L. Hudson (Eds.), Phenological research: Methods for enviromental and climate change analysis (pp. 357-371). New York, USA: Springer.

Morellato, L.P.C., Camargo, M.G.G., \& Gressler, E. (2013). A review of plant phenology in South and Central America. In M.D. Schwartz (Ed.), Phenology: An integrative environmental science (pp. 91-113). The Netherlands: Springer.

Morellato, L.P.C., Talora, D.C., Takahasi, A., Bencke, C.C., Romera, E.C., \& Ziparro, V. (2000). Phenology of Atlantic rain forest trees: a comparative study. Biotropica, 32, 811-823.

Mori, S.A., \& Pipoli, J.J. (1984). Observations of the big bang flowering of Miconia minutiflora (Melastomataceae). Brittonia, 36, 337-341.

Murali, K.S., \& Sukumar, R. (1994). Reproductive phenology of a tropical dry forest in Mudumalai, Southern India. Journal of Ecology, 82, 759-767.

Nadia, T.L., Morellato, L.P.C, \& Machado, I.C. (2012). Reproductive phenology in a northeast Brazilian mangrove community: Environmental and biotic constrains. Flora, 207, 682-692.

Newstrom, L.E., Frankie, G.W., \& Baker, H.G. (1994). A new classification for plant phenology based on flowering patterns in lowland tropical rain forest trees at La Selva, Costa Rica. Biotropica, 26, 141-159.

Nuñez-Cruz, A., Meave, J.A., \& Bonfil, C. (2018). Reproductive phenology and seed germination in eight tree species from a seasonally dry tropical forest of Morelos, Mexico: Implications for community oriented restoration and conservation. Tropical Conservation Science, 11, 1-14.

Parrini, R., Raposo, M.A. Hoyo, J.D., \& Silva, A.D. (2012). Schefflera morototoni (Araliaceae) como importante recurso alimentar para as aves durante a estação seca na Amazônia central. Cotinga, 35, 3-6.

Pires, J.P.D.A., Silva, A.G.D., \& Freitas, L. (2014). Plant size, flowering synchrony and edge effects: What, how and where they affect reproductive success 
of a Neotropical tree species. Austral Ecology, 39 , 328-336.

Poulin, B., Wright, S.J., Lefebvre, G., \& Calderón, O. (1999). Interspecific synchrony and asynchrony in the fruiting phenologies of congeneric bird-dispersed plants in Panama. Journal of Tropical Ecology, 15, 213-227.

Rathcke, B., \& Lacey, E.P. (1985). Phenological patterns of terrestrial plants. Annual Review Ecology and Systematics, 16, 179-214.

SanMartin-Gajardo, I., \& Morellato, L.P.C. (2003). Inter and intraspecific variation on reproductive phenology of Brazilian Atlantic forest Rubiaceae: ecology and phylogenetic constrains. Revista de Biología Tropical, 51, 691-698.

Saracco J.F., Collazo, J.A., Groom, M.J., \& Carlo, T.A. (2005). Crop size and fruiting Schefflera morototoni tree in Puerto Rico. Biotropica, 37, 81-87.

Sardi, A., Torres, A.M., \& Corredor, G. (2018). Diversidad florística en un paisaje rural del piedemonte de los Farallones de Cali, Colombia. Colombia Forestal, $21,142-160$.

Smith-Ramírez, C., Armesto, J.J., \& Figueroa, J. (1998). Flowering, fruiting and seed germination in Chilean rain forest Myrtaceae: ecological and phylogenetic constraints. Plant Ecology, 136, 119-131.

Singh, K.P., \& Kushwaha, C.P. (2006). Diversity of flowering and fruiting phenology of trees in a tropical deciduous forest in India. Current Science, 97, 265-276.

Sokal, R.R., \& Rohlf, F.J. (1995). Biometry: The Principles and Practice of Statistics in Biological Research. New York, USA: W.H. Freeman and Co.

Staggemeier, V.G., Diniz-Filho, J.A.S., \& Morellato, L.P.C (2010). The shared influence of phylogeny and ecology on the reproductive patterns of Myrtae (Myrtaceae). Journal of Ecology, 98, 1409-1421.

Sun, C., Kaplin, B.A., Kristensen, K.A, Munyaligoga, V., Vukiyumwami, J., Kajondo, K., \& Moermond, T.C. (1996). Tree phenology in a tropical montane forest in Rwanda. Biotropica, 28, 668-681.
Thies, W., \& Kalko, E.K.V. (2004). Phenology of neotropical pepper plants (Piperaceae) and their association with the main dispersers, two short-tailed fruit bats, Carollia perspicillata and C. castanea (Phyllostomatidae). Oikos, 104, 362-376.

van Schaik, C.P., Terborgh, J.W., \& Weight, S.J. (1993). The phenology of tropical forests: Adaptative significance and consequences for primary consumers. Annual Review Ecology and Systematics, 24, 353-377.

Vilchez, B., \& Rocha, O. (2007). Fenología reproductiva de las especies del dosel superior en seis sitios de la Región Huetar Norte de Costa Rica. Revista Forestal Mesoamericana Kurú, 4, 1-16.

Villasana, R.A., \& Suarez, A. (1997). Estudio fenológico de dieciséis especies forestales presentes en la reserva forestal Imataca Estado Bolívar-Venezuela. Revista Forestal Venezolana, 41, 13-21.

Wheelwright, N.T. (1986) A seven-year study of individual variation in fruit production in tropical bird-dispersed tree species in the family Lauraceae. In A. Estrada \& T.H. Fleming (Eds.), Frugivores and seed dispersal (pp. 19-35). Dordrecht, the Netherlands: Junk Publishers.

Williams-Linera, G., Dominguez-Gastelu, V., \& GarciaZurita, M.E. (1998). Microenvironment and floristics of different edges in a fragmented tropical rainforest. Conservation Biology, 12, 1091-1102.

Williams-Linera, G., \& Meave, H. (2002). Patrones fenológicos. In M.R. Guariguata \& G.H. Kattan (Eds.), Ecología y Conservación de Bosques Neotropicales (pp. 407-431). Cartago, Costa Rica: Libro Universitario Regional.

Wright, S.J., \& Calderón, O. (1995). Phylogenetic patterns among tropical flowering phenologies. Journal of Ecology, 83, 937-948.

Xiao, Y., Li, X., Cao, Y., \& Dong, M. (2016). The diverse effects of habitat fragmentation on plant-pollinator interactions. Plant Ecology, 217, 857-868.

Zar, J.H. (2010). Biostatistical analysis (5 ${ }^{\text {th }}$ Ed.). New Jersey, USA: Pearson. 